Kvasnikov V.,
Matviyenko D.

\title{
VISUALIZATION OF THE STATE OF RADIOLOGICAL CONTAMINATION OF FOOD PRODUCTS
}

Об’єктом дослідження є вимірювання, оцінювання, візуалізащія $i$ контроль впливу радіаційного опромінення на життя, здоров'я громадян, охорони довкілля та безпеки народногосподарських об'єктів з урахуванням ризику виникнення техногенних катастроф. Однією з найбільших проблем є потреба в розробці наукових методів дослідження комплексних оцінок впливу техногенних навантажень на навколишнє середовище та людину. А також у створенні спеціалізованих систем, призначених для збору, зберігання, обробки та візуалізачї̈ інформачї̈ з використанням сучасних ГІС (геоінформачійних систем) технологій. Це дозволяє аналізувати багатомірні дані за допомогою їх відображення із збереженням структурних особливостей інформаціі.

В ході дослідження використовувалась комплексна оцінки впливу техногенного забруднення, що є необхідною умовою метрологічного забезпечення для поглибленого дослідження структури системи, як єдність компонентів та зв'язків.

В результаті проведеної роботи сформовано спеціалізовану систему аналізу даних, отриманих при вимірюванні зразків харчової продукиї, на відповідність вимогам стандартів на ту чи іншу продукцію. В основі даної системи знаходиться розробка бази даних харчового моніторингу Черкаської області (Украӥна), структура якої включає центральний банк $і 5$ спеціалізованих блоків. Наводяться приклади розрахунку порівняльних очінок стану районів області, включаючи радіачійну складову.

Проведено вимірювання та отриманий контроль над складною обстановкою при одночасному обліку великої кількості різнорідних параметрів. Це пов'язано з тим, що запропонований метод доповнює відомі методи математичного моделювання радіологічного забруднення, що напряму впливають на якість життя населення, та має ряд особливостей. Зокрема, розроблення програмного середовища для побудови та візуалізації у вигляді тематичних карт кореляційної залежності між радіологічним забрудненням і захворюваністю населення регіону. Завдяки цьому забезпечується можливість отримання оцінки ступеню ризику для здоров'я населення та прийняття обгрунтованих рішень для його мінімізацї̈.

Ключові слова: візуалізація радіаційного забруднення, факторний аналіз, кластерний аналіз, радіологічне картографування.

\section{Introduction}

Data visualization is a way of representing multidimensional data distribution, in which the basic regularities inherent in the original distribution are qualitatively reflected: cluster structure, topological features, internal system connections, distances in the original feature space, etc. Traditional tools in this area are graphs and charts poorly cope with the task of visualization, when it becomes necessary to depict more than three interrelated quantities.

On the other hand, there is a powerful tool for displaying information tied to a geographic grid of coordinates [1].

Radiological mapping and forecasting are closely related to radiological and food monitoring. In this case, mapping (mapping of radiological indicators) should be considered as the basis of monitoring, and forecasting - as its most important consequence. For a number of reasons, these works in Ukraine were obviously carried out in limited volumes and with insufficient completeness. Their main drawback was that, until recently, radiological mapping and forecasting was carried out, in essence, as radiation, spectrometric or radio geochemical measurements [2].

For a significant part of Ukraine, in the sense of a comprehensive assessment of the radiological situation, much less has been done than for the 30-kilometer zone. At the same time there are significant amounts of analytical data, mainly on the density of ${ }^{137} \mathrm{Cs}$ contamination, which constitute many hundreds of thousands gradations. When all accumulated information is concentrated in electronic databases, the problem of integrated radiological mapping of the territory of Ukraine could be solved quite successfully and within a reasonable timeframe [3].

Therefore, the study of integrated assessment of the impact of radionuclides on the environment and the population is directly relevant, directly affecting the quality of life of the population, reflecting the current state of the environment and the health of the population in the region.

\section{The object of research and its technological audit}

The object of research is the measurement, assessment, visualization and control of the effects of radiation exposure on life, public health, environmental protection and safety of national economic facilities, taking into account the risk of man-made disasters.

The problems of research of the migration of radionuclides in food chains require the use of information technology in the process of research and the implementation of mathematical models in applied software packages [4, 5]. 
Up to the present, radiological mapping is presented mainly in the form of radiation or radio geochemical maps. The main attention, as before, is paid to the contamination density of the area by the main man-made radionuclides, and a wide range of indicators related to the impact of the catastrophe on the biosphere and the population of the adjacent territories, have not received an adequate cartographic representation.

One of the biggest problems is the need to develop scientific methods for the study of integrated assessments of the impact of man-made pressures on the environment and humans. And also in the creation of specialized systems for collecting, storing, processing and visualizing information using modern GIS (geographic information systems) technologies. This allows to analyze multidimensional data using their display while preserving the structural features of the information.

\section{The aim and objectives of research}

The aim of research is creation of a specialized system for collecting, analyzing and visual interpretation of food monitoring data, which would include a database, means of graphical presentation of information, software for environmental protection tasks and cartographic modeling of man-made pollution.

To achieve this aim it is necessary to perform the following tasks:

1. Develop approaches, methodologies and software tools that greatly simplify the analysis of heterogeneous data.

2. Conduct zoning of the territory of the Cherkasy region (Ukraine) by radiological indicators of ${ }^{137} \mathrm{Cs}$ and ${ }^{90} \mathrm{Sr}$ content and identify and visualize the relationship between levels of man-made pollution and the incidence of the population.

\section{Research of existing solutions of the problem}

When analyzing software products used for radiological research, it was revealed that, to date, software products are used in research, the main purpose of which is visualization of the investigated process or phenomenon.

There is a fairly wide range of mathematical models in radiology and the software in which they are implemented. Among them:

USLE. The model developed in the 80 s of the last century satisfies neither the modern level of science nor the demands of practice. This model needs to be improved, which should occur in several areas, including: updating the information base, further research on the patterns of spatial differentiation of erosion process factors and the development of methods for their geoinformation modeling [6].

Food Web. Analysis of the mathematical model allows to answer important informative questions about the features of the dynamics of interacting populations and predict their behavior in the future. Such transition is accompanied by the loss of stability of a simple attractor - equilibrium and the birth of a new, more complex attractor of the limit cycle. There is a mandatory union of all food chains, and only a small part of this complex system illustrates the real ecosystem [7].

ECORAD. The main advantage of this method is the mathematical solution of the problem of lack of parame- ters, and the success of implementation depends on the correctness of the problem statement, the dimension of the system, the number of unknown parameters and the accuracy of the presented experimental data. There are quite a few ways to solve them today. The main disadvantage of these models is a significant number of unknown parameters characterizing the speed of the processes occurring in the compartments [8].

Stella. The advantages include a good graphing system, which allows to scale the graph, to place several graphs on the same page. The disadvantage of this approach is a large amount of preliminary transformations; besides, the structure of the model does not resemble a real system, or it may not even have equivalent circuit and is a set of equations [9].

POSEIDON. It allows describing the migration of various radionuclides - from describing the source of pollution to estimating the doses of internal human exposure as a result of the consumption of seafood. The POSEIDON model was used to study the consequences of the accident at the Japanese nuclear power plant Fukushima-1 (March 2011). The disadvantage is that it describes only the marine environment, including the water column, bottom sediments and marine organisms and does not describe the food chains of land [10].

THREETOX. It provides the ability to predict the shortterm transfer of radionuclides in various reservoirs: rivers, lakes, reservoirs, estuaries and coastal zones of the seas. Among the shortcomings can be identified the complexity of the numerical solution of equations and the need for powerful computing resources [11].

These models, which show the use of mathematical modeling in radiology and at the same time, serve as a kind of reference for scientists working in the field of research of radiological processes. The above examples of models were implemented in non-commercial specialized software packages. As part of the generalization of the analysis of mathematical models, it can be concluded that the compartmental models that make up ecosystems describe the kinetics of processes of a similar nature. Models of the behavior of radionuclides in the environment (air, water, soil solution) are described mainly by diffuse convective transport equations (often simplified modifications are used), since migration of radionuclides is promoted by processes such as diffusion, convection and advection.

The models of these literary sources for forest ecosystems are mainly described by systems of ordinary differential equations. Although the number of models is quite significant, only some of the mathematical models developed in recent years have found their implementation in applied software systems.

But the disadvantage of these inspections is the lack of systematization of the tasks of general ecology and radioecology. In addition, these reviews only show the application of systems analysis in a specific narrow area of environmental sciences. From the point of view of systematization of the tasks of environmental sciences, these reviews characterize unsatisfactorily the current state of affairs in this subject area.

There are also a number of published reviews of the application of methods of mathematical modeling in radiology and radiobiology [12]. One should not think that any interrelationships can be described by a model in the form of a system of differential equations, which would 
be subjected to research in the classical sense, that is, integration in the formula or at least qualitative research. Ecosystems need to be studied as a whole, not limited to only those species that are of economic interest to humans. Mathematical modeling of any ecological system is a large, long and expensive experiment that has very little chance of success.

Thus, in studies [13], the dependences of the accumulation of radionuclides in the compartments of plants, fungi, etc. are given. However, in this work the further migration of radionuclides along trophic chains to humans is not fully represented.

Thus, in [14], a mathematical model is implemented that takes into account the physical features of the distribution of ${ }^{90} \mathrm{Sr}$ radionuclides along the soil profile, taking into account soil and minimizing processes. But the question remains of the further accumulation of radionuclides in various types of plant products. The main advantage of the model is that it is based on simple algorithms. However, they are not informative and graphical visualization and control of the modeling process are not considered.

In $[15,16]$, in addition to the presentation of the methodology for system analysis of environmental changes, bringing formalized descriptions of the stages of building mathematical models, mathematical models of ecosystems were proposed, in particular, the analysis of the migration of radionuclides along the trophic chain «surface phytomass - man». However, the incidence of diseases against the background of radiological contamination has not been resolved.

It is shown that the desire for a more accurate description of a complex system object leads to an increase in the number of factors and processes taken into account, which makes it difficult to use mathematical models. Analysis and forecast of such models is performed with an error, which is caused by the accuracy of the methods, inaccuracy of the source data. These errors lead to catastrophic inaccuracies in model predictions. It is necessary to thoroughly study the interrelationships of natural and anthropogenic systems, modern methods for assessing and forecasting such relationships, reducing the number of factors taken into account.

In [3], the possibilities of expanding the usual mapping of the radiation situation at the radiological level of mapping were first demonstrated. A set of maps for the northern territories of Ukraine has been prepared. They include maps of the state of the environment, a summary map of ${ }^{137} \mathrm{Cs}$ surface contamination density, a map of the biogenic radionuclide migration, a map of the incidence rate of children's population, and a resulting map of the degree of radiological danger of residence in the territory of Ukrainian Polesie. In this work, only the assessment of the contamination density of the area with the main man-made radionuclides was performed. However, a wide range of indicators reflecting the impact of the Chernobyl catastrophe on the biosphere, especially such as morbidity, working capacity of the population, fertility, mortality, life expectancy, etc. is not shown in the map.

So, from the analysis of the well-known software and mathematical methods, it can be seen that the disadvantages of these examinations are the lack of systematization of general radiology tasks. Observation of the state of radiation contamination requires filtering loads (factors) to obtain an informative component about the state of contamination and the rate of migration of radionuclides along trophic chains.

\section{Methods of research}

The construction of radiological maps, which include many different indicators, requires intensive theoretical and methodological studies. First, it is necessary to carry out a comprehensive analysis of heterogeneous measurements of the affected ecosystem, and then make the transition from a simple assessment of the radiation situation to integral assessments of the radiological consequences of pollution for a region, its individual territories and main categories of the population.

Mathematical statistics here acts primarily as a way to summarize information about the set of objects, allows to synthesize data on the part (elements of the statistical population) into information about the whole (about the entire statistical population). Methods of multivariate statistical analysis turned out to be the most adequate means for the transition from a set of disparate pollution indicators to generalized radiological indices and their cartographic representation [17, 18].

From the conducted comparative analysis, it is possible to conclude that the maps represent a reliable means for visualization and as a guide to the modeling process, to control and correct it, as well as to evaluate the benefits of specific mathematical models.

Multidimensional statistical analysis and methods for visual interpretation of multidimensional data (namely, factor, cluster methods) will be used as a device for research and prediction of complex medical and radiological situations. They are closely connected with atmospheric pollution of large industrial cities of Ukraine against the background of their radiation pollution, etc. [19, 20].

The basic model of factor analysis is described by the formula:

$$
F_{k}=\sum_{i} a_{k i} X_{i}
$$

where $X_{i}$ - the initial data array; $i$ - the number of columns of the initial matrix; $k$ - the number of selected factors; $F_{k}$ - common factors; $a_{i k}$ - specific factors.

The factors $F_{m}$ are structured so that in the best way (with the minimum error) to represent $X_{n}$. In this model, the «hidden» variables $F_{k}$ are called common factors, and the variables $U_{i}$ are specific factors. «Specific» is only one of the translations used in the English-language literature of the word Unique, in Ukrainian literature as the definition of $U_{i}$ there are also the words «characteristic», «unique». The value of $a_{i k}$ is called factor loadings [21].

The tree clustering method is used when forming clusters of differences or distances between objects. These distances can be determined in one-dimensional or multidimensional space. The most direct way to calculate distances between objects in a multidimensional space is to calculate Euclidean distances (2).

The Euclidean distance is a geometric distance in multidimensional space and is the distance between points $x$ and $y$ in $n$-dimensional space and is calculated as follows:

$$
d(x, y)=\left\{\sum_{i}\left(x_{i}-y_{i}\right)^{2}\right\}^{1 / 2},
$$

where $x$ and $y$ are points in $n$-dimensional space. 


\section{Research results}

The initial data for cluster analysis are the factor values of the districts of the Cherkasy region, which were obtained on the basis of the state enterprise Cherkasy Research and Production Center for Standardization, Metrology and Certification (Ukraine), Table 1. The use of cluster analysis will make it possible to regionalize the territory of the Cherkasy region on some grounds, which can be used to make the same decisions in the field of monitoring food monitoring data, data visualization or public health [17].

To determine the distances between the objects of research, let's use the Euclidean distance. This is due to the fact that the considered areas are in two-dimensional space (Table 2).

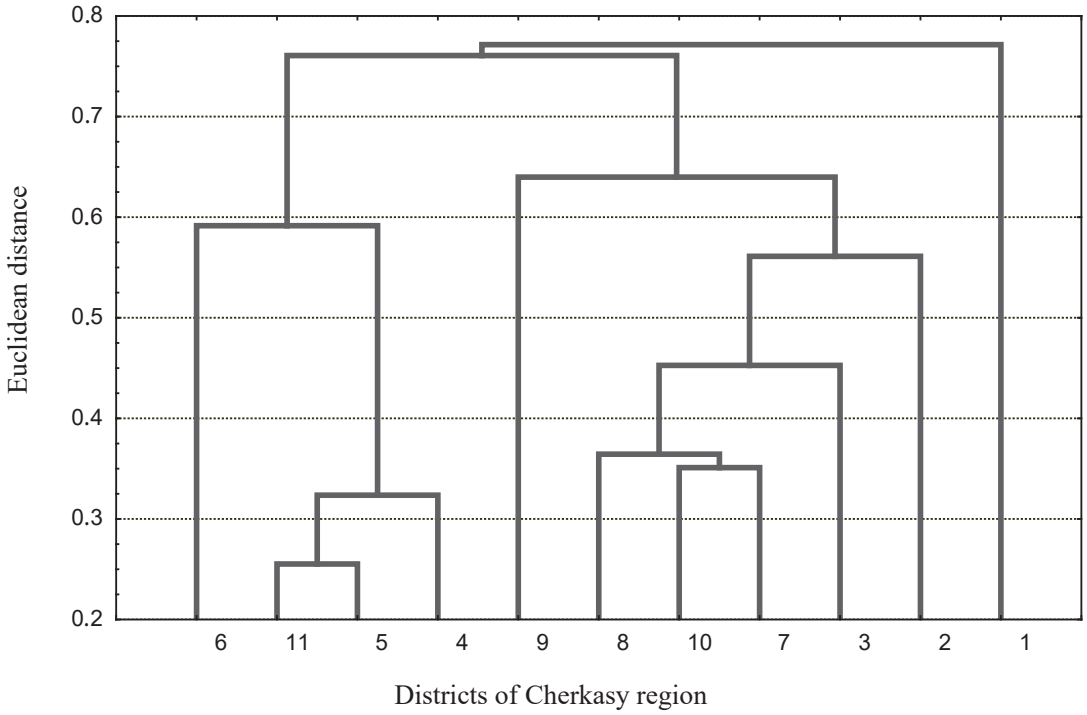

Fig. 1. Diagram of clustering districts of Cherkasy region (Ukraine)

Table 3
Table 1

Factor values of districts of Cherkasy region (Ukraine), which were obtained at the previous stage of research

\begin{tabular}{|c|c|c|c|}
\hline District & Designation & Factor 1 & Factor 2 \\
\hline Horodyshche & 1 & 0.870556 & -2.64258 \\
\hline Zhashkiv & 2 & -0.14365 & 0.035108 \\
\hline Zvenyhorodka & 3 & -0.08104 & -0.71978 \\
\hline Kaniv & 4 & -1.39225 & -0.05446 \\
\hline Katerynopil & 5 & -0.98527 & 0.197562 \\
\hline Korsun-Shevchenkovsky & 6 & -1.22781 & 0.446697 \\
\hline Lysianka & 7 & 0.507724 & 0.306024 \\
\hline Talne & 8 & 0.688488 & 0.653968 \\
\hline Uman & 9 & 0.313546 & 1.325073 \\
\hline Shpola & 10 & 0.435119 & -0.27887 \\
\hline Cherkasy & 11 & -0.95288 & -0.19726 \\
\hline
\end{tabular}

As a result of the analysis by the tree clustering method, the following tree diagram is obtained (Fig. 1).

Fig. 1 shows that the districts are clearly divided into 3 groups (Table 3 ).
Dividing of districts of Cherkasy region (Ukraine) into clusters

\begin{tabular}{|c|c|c|}
\hline No. of district & Name of district & Cluster \\
\hline 11 & Cherkasy & 1 \\
\hline 6 & Korsun-Shevchenkovsky & 1 \\
\hline 5 & Katerynopil & 1 \\
\hline 4 & Kaniv & 1 \\
\hline 9 & Uman & 2 \\
\hline 3 & Zvenyhorodka & 2 \\
\hline 10 & Shpola & 2 \\
\hline 8 & Talne & 2 \\
\hline 7 & Lysianka & 2 \\
\hline 2 & Zhashkiv & 2 \\
\hline 1 & Horodyshche & 3 \\
\hline
\end{tabular}

Using GIS, the following information is presented in a visual form. To display the results of cluster analysis, the MapInfo Professional 6 GIS is used. The obtained results allow to construct maps of the dynamics of grouping changes in the districts of Cherkasy region by clusters for 2013-2016. And accordingly, to visually assess the change in

Tahle 2

Matrix of Euclidean distances between the districts of the Cherkasy region (Ukraine)

\begin{tabular}{|c|c|c|c|c|c|c|c|c|c|c|c|}
\hline $\begin{array}{c}\text { Designation of the } \\
\text { district in Cherkasy } \\
\text { region }\end{array}$ & 1 & 2 & 3 & 4 & 5 & 6 & 7 & 8 & 9 & 10 & 11 \\
\hline 1 & 0 & 2.863 & 2.1454 & 3.438 & 3.393 & 3.735 & 2.971 & 3.3 & 4.007 & 2.4035 & 3.05 \\
\hline 2 & 2.8633 & 0 & 0.7575 & 1.252 & 0.1067 & 1.16 & 0.705 & 1.04 & 1.369 & 0.6584 & 0.842 \\
\hline 3 & 2.1454 & 0.757 & 0 & 1.47 & 1.288 & 1.636 & 1.183 & 1.57 & 2.083 & 0.6788 & 1.016 \\
\hline 4 & 3.4378 & 1.252 & 1.4703 & 0 & 0.479 & 0.527 & 1.934 & 2.2 & 2.194 & 1.8411 & 0.462 \\
\hline 5 & 3.3927 & 0.857 & 1.2881 & 0.479 & 0 & 0.348 & 1.497 & 1.73 & 1.72 & 1.4982 & 0.396 \\
\hline 6 & 3.7345 & 1.16 & 1.6358 & 0.527 & 0.348 & 0 & 1.741 & 1.93 & 1.774 & 1.8143 & 0.7 \\
\hline 7 & 2.9708 & 0.705 & 1.1828 & 1.934 & 1.497 & 1.741 & 0 & 0.39 & 1.037 & 0.5894 & 1.545 \\
\hline 8 & 3.3016 & 1.037 & 1.5746 & 2.198 & 1.735 & 1.927 & 0.392 & 0 & 0.769 & 0.9666 & 1.849 \\
\hline 9 & 4.0066 & 1.369 & 2.0826 & 2.194 & 1.72 & 1.774 & 1.037 & 0.77 & 0 & 1.6085 & 1.98 \\
\hline 10 & 2.4035 & 0.658 & 0.6788 & 1.841 & 1.498 & 1.814 & 0.589 & 0.97 & 1.609 & 0 & 1.39 \\
\hline 11 & 3.0503 & 0.842 & 1.0164 & 0.462 & 0.396 & 0.7 & 1.545 & 1.85 & 1.98 & 1.3904 & 0 \\
\hline
\end{tabular}
contamination by radionuclides of food products in different parts of the region for separate periods of time (Fig. 2).

The basis of the specialized system is the development of a database of medical radiological and food monitoring of the Cherkasy region, the structure of which includes a central bank and 5 specialized units. The process of data visualization in the form of thematic maps is described, the correlation dependencies between atmospheric pollution, ${ }^{137} \mathrm{Cs},{ }^{90} \mathrm{Sr}$ foodstuffs contamination and the morbidity of the population of the studied areas are analyzed. 
Examples are given of the calculation of comparative assessments of the radiological state of areas, including the radiation component.

The developed software package, taking into account such a database, is presented in Fig. 3.

The next step is creation of thematic maps. It is shown that visualization of data is the best way to interpret pollution and disease. This allows not only to analyze the data in a convenient form, but also to predict pollution in a particular area. The regions of the region are stained for the pollution of basic foodstuffs according to the gradations. For each district, a column of morbidity per 10 thousand people is built - respiratory organs, blood of the gastrointestinal, endocrine, nervous, urogenital systems. As an example, Fig. 4 shows the result of such visualization.

The high level of environmental pollution in Ukraine leads to the degradation of ecosystems, an increase in the incidence of the population and the deterioration of demographic indicators. These problems are especially important for technologically-loaded regions of Ukraine, including Cherkasy region, which is industrialized, with a high level of urbanization. A powerful energy base has been created in the region, which has become the basis for the development of the chemical industry.

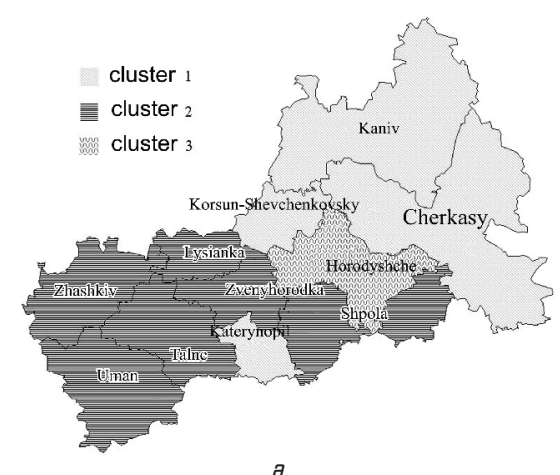

$a$

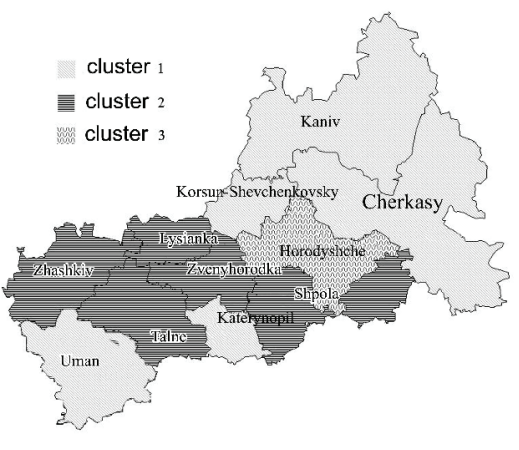

$c$

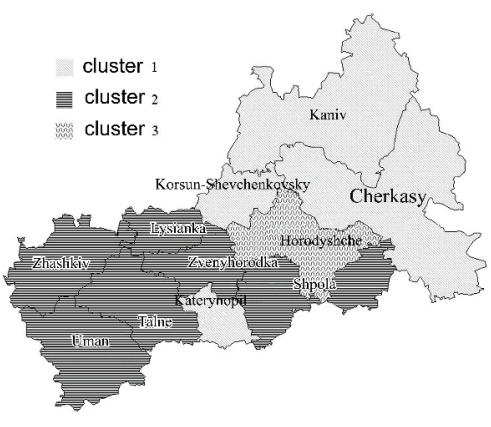

$b$

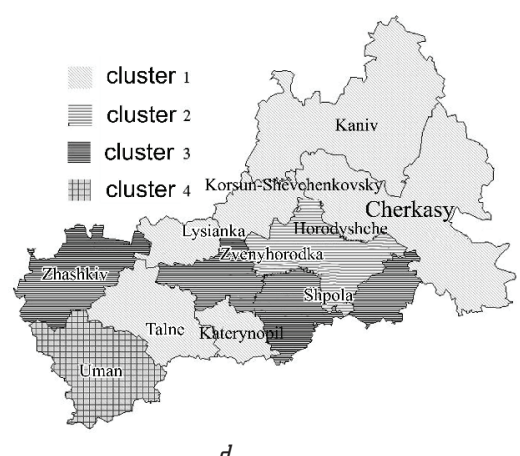

Fig. 2. Dynamics of clustering districts on maps for: $a-2013$; $b-2014 ; c-2015 ; d-2016$

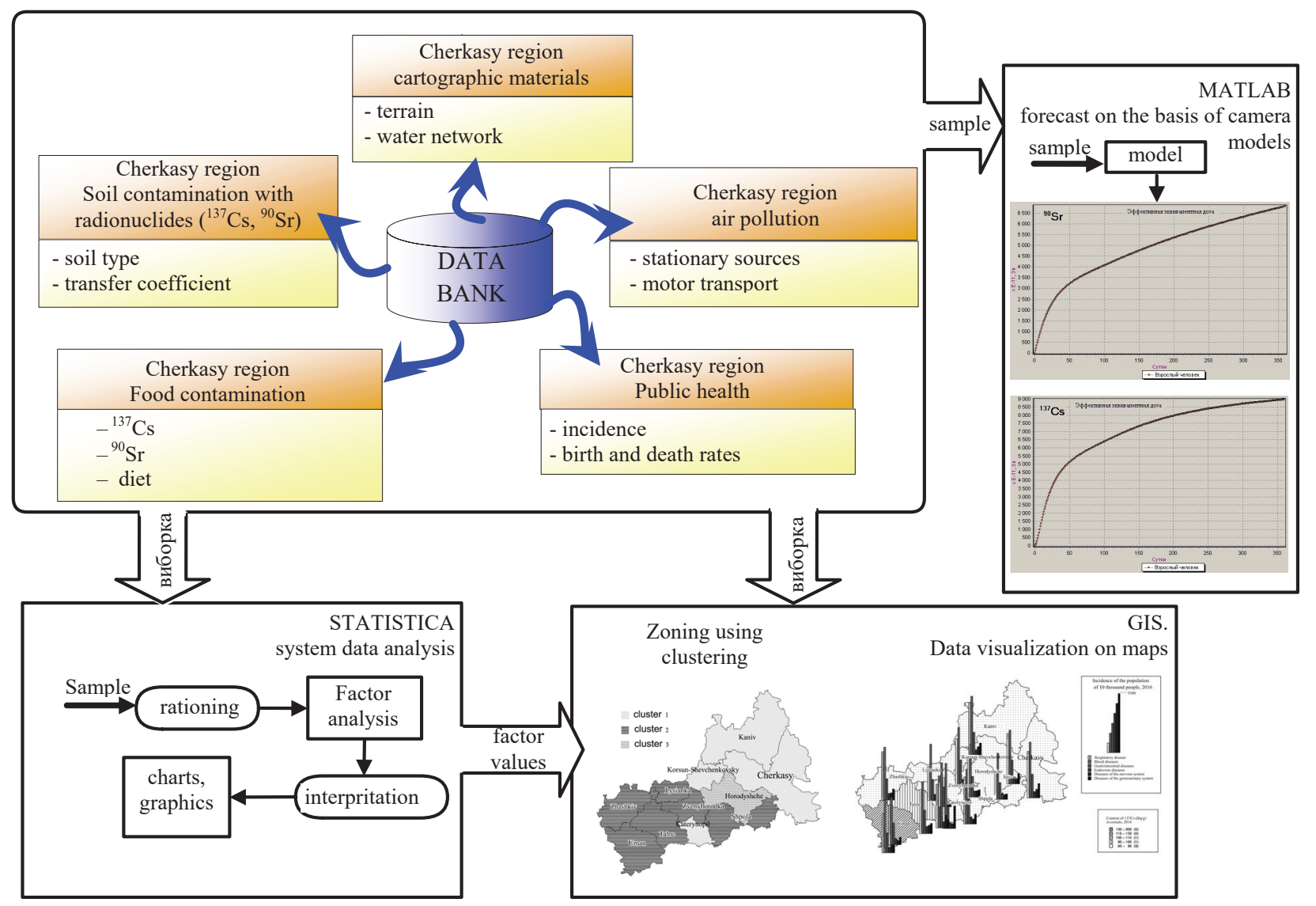

Fig. 3. Structure of the developed software package 

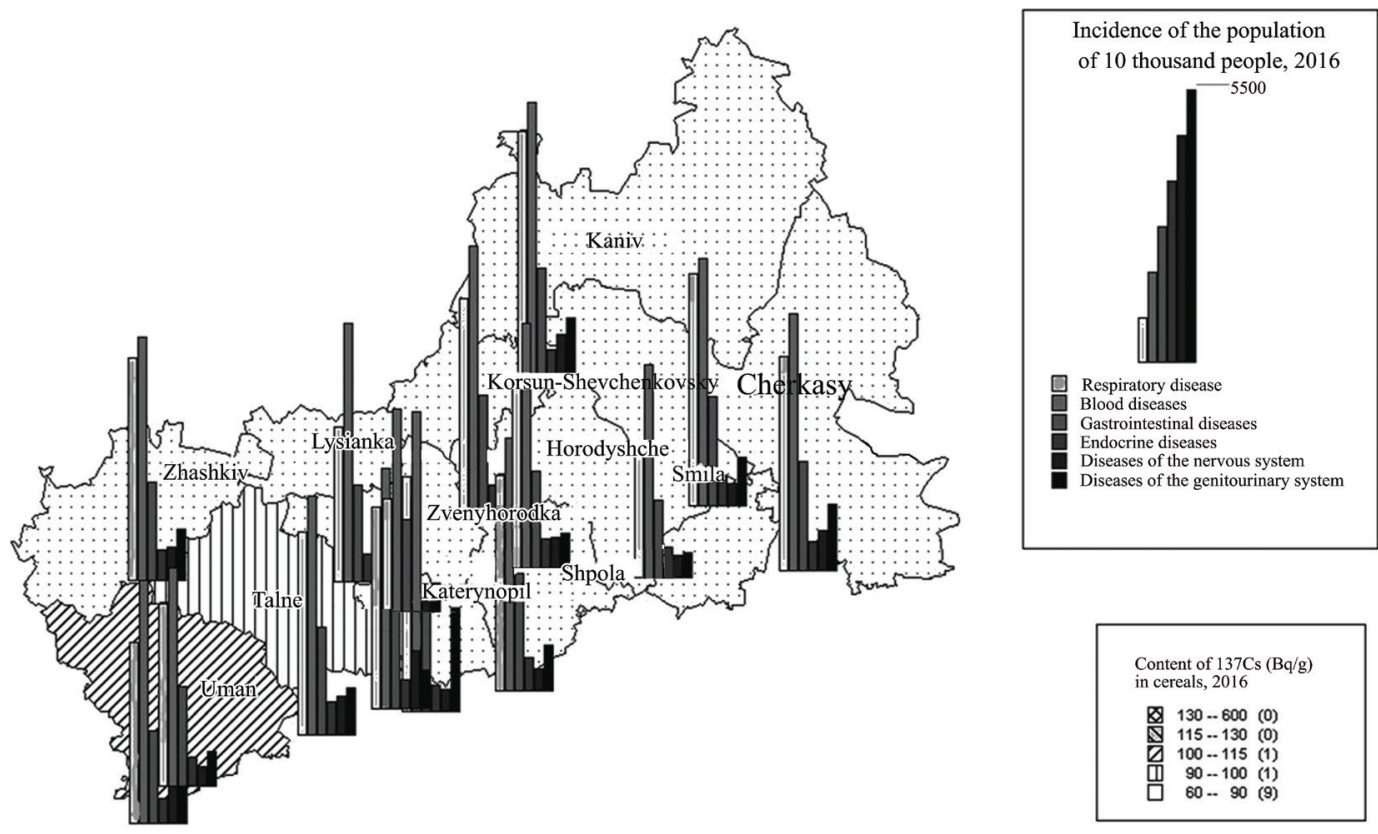

Fig. 4. Visualization of ${ }^{137} \mathrm{Cs}$ content background incidence data

Therefore, there is a well-established tendency of the need to assess the state of environmental pollution not only by traditional physicochemical methods; they establish the actual values of concentrations of various pollutants, but also by using bioindication methods. The latter, as is well known, provide an answer to the question of the overall toxicity and mutagenicity of polluted environmental objects and their degree of danger to biota and humans. That is, they contribute to solving a number of important radiological problems in the system of sustainable development of the chemical region and the state as a whole.

\section{SWOT analysis of research results}

Strengths. A specialized system has been developed for the collection, analysis and visual interpretation of monitoring data and monitoring data for compliance with the requirements of standards in food production. This system includes a database, means of graphical representation of information, cartographic modeling of man-made pollution and provides data processing in real time.

Weaknesses. There is a need to create a separate specialized system for each region, which is associated with the specifics of nutrition of the population of the region and different from other regions, the nature of radiological contamination.

Opportunities. It is shown that visualization of data is the best way to interpret pollution and disease. This allows not only to analyze the data in a convenient form, but also to respond more quickly and productively to the increased activity of the radionuclides ${ }^{90} \mathrm{Sr}$ and ${ }^{137} \mathrm{Cs}$ at any stage from production to consumption.

This information will be very useful for agricultural producers who are interested not only in the preservation of significant financial resources, but also in the production of clean raw materials.

Threats. An additional cost would be required by the enterprise, farm or supervisory authority to develop a database of radiological monitoring, as well as laboratory measurements of food.

\section{Conclusions}

1. As a result of the work, a specialized system for analyzing the data obtained when measuring samples of food products for compliance with the requirements of standards for a particular product is formed. The basis of this system is the development of a database of food monitoring in the Cherkasy region (Ukraine), the structure of which includes a central bank and 5 specialized units. Examples are given of the calculation of comparative assessments of the state of areas of the region, including the radiation component. Taking into account such database, a software package is developed that allows not only to analyze the data obtained in a convenient form, but also to predict pollution in a particular area.

2. A comprehensive analysis of the monitoring data for the areas of the Cherkasy region is carried out using the developed algorithmic and software tools, and the zoning of the contaminated territories is carried out by radiological indicators. The correlation dependencies between ${ }^{137} \mathrm{Cs},{ }^{90} \mathrm{Sr}$ food contamination levels and the incidence in certain areas are studied in order to protect the interests of consumers, export quality of regional products, protect public life, human health, and protect the environment. The results of the analysis are presented in the form of thematic maps.

\section{References}

1. Konovalova N. V., Kapralov E. G. Vvedenie v GIS: textbook. Moscow, 1997. $160 \mathrm{p}$.

2. Katorgin I. Yu., Naydenko V. N., Petin O. V. Geoinformatsionnaya sistema Maplnfo: textbook. Stavropol: Izd-vo SGU, 2002. 54 p

3. Sobotovich E. V., Shestopalov V. M., Pushkarev A. V.. Printsipy landshaftno-geokhimicheskogo i radioekologicheskogo kartirovaniya territorii, zagryaznennoy tekhnogennymi radionuklidami. Dokl. AN Ukrainy. 1993. Issue 1. P. 177-181.

4. Chernobyl Digest 95-98// Interdisciplinary Bulletin of the Chernobyl Problem Information. Issue 5. Minsk, 1999. $257 \mathrm{p}$.

5. Serdyutskaya L. F. Tekhnogennaya ekologiya. Matematiko-kartograficheskoe modelirovanii. Moscow: Knizhnyy dom «LIBROKOM», 2009. 232 p. 
6. Mitas L., Mitasova H. Distributed soil erosion simulation for effective erosion prevention // Water Resources Research. 1998. Vol. 34, Issue 3. P. 505-516. doi: http://doi.org/10.1029/ 97wr03347

7. Krivan V. Competition in di- and tri-trophic food web modules // Journal of Theoretical Biology. 2014. Vol. 343. P. 127-137. doi: http://doi.org/10.1016/j.jtbi.2013.11.020

8. Handbook of parameter values for the prediction of radionuclide transfer in terrestrial and freshwater environments Technical reports series No. 472. Vienna: IAEA, 2010. 194 p.

9. Kozak I. I. Ekolohichne modeliuvannia iz zastosuvanniam prohramy STELLA. Ivano-Frankivsk: Plai, 2009. 189 p.

10. Lepicard S., Heling R., Maderich V. POSEIDON/RODOS models for radiological assessment of marine environment after accidental releases: application to coastal areas of the Baltic, Black and North Seas // Journal of Environmental Radioactivity. 2004. Vol. 72, Issue 1-2. P. 153-161. doi: http://doi.org/ 10.1016/s0265-931x(03)00197-8

11. Margvelashvily N., Maderich V., Zheleznyak M. THREETOX A Computer Code to Simulate Three-Dimensional Dispersion of Radionuclides in Stratified Water Bodies // Radiation Protection Dosimetry. 1997. Vol. 73, Issue 1. P. 177-180. doi: http://doi.org/10.1093/oxfordjournals.rpd.a032128

12. Metody ta zasoby matematychnoho modeliuvannia mihratsii radionuklidiv u pryrodnykh ekosystemakh: Vol. 1. Vid analizu do matematychnoi modeli. / Yanchuk V. M. et. al. Zhytomyr: ZhITI, 2002. 142 p.

13. Mamikhin S. V., Merkulova L. N. Komp'yuterizatsiya issledovaniy dinamiki radionuklidov v lesnykh ekosistemakh, zagryaznennykh v rezul'tate Chernobyl'skoy avarii (1986-1995 gg.) // Radiatsionnaya biologiya. Radioekologiya. 1996. Vol. 36, Issue 4. P. 516-523.

14. Otsenka stepeni zagryazneniya pochv 137Cs, dopuskayushhey poluchenie normativno chistoy sel'skokhozyaystvennoy produktsii, na osnove matematicheskikh modeley perekhoda radionuklida v rasteniya / Spiridonov S. I. et. al. // Sel'skokhozyaystvennaya biologiya. 2008. Issue 5. P. 53-57.

15. Serdyutskaya L. F., Kamemeneva I. P. Sistemnyy analiz i matematicheskoe modelirovanie mediko-ekologicheskikh posldstviy avarii na CHAES i drugikh tekhnogennikh vozdeystviy. Kyiv: «Medekol» MNITS BIO-EKOS MCHS i NAN Ukrainy, 2000. P. 173.

16. Serdyutskaya L. F., Kameneva I. P. Tekhnogennaya ekologiya Matematiko-kartograficheskoe modelirovanii. Moscow: Knizhnyy dom «LIBROKOM», 2009. 232 p

17. Dubrov A. M., Mkhitaryan V. S., Troshin L. I. Mnogomernye statisticheskie metody. Moscow: Finansy i statistika, 1998. $232 \mathrm{p}$.

18. Khalafyan A. STATISTICA 6. Statisticheskiy analiz dannykh. Binom, 2010. 512 p.

19. Ivchenko B. P., Martyshhenko L. A. «Informatsionnaya ekologiya». Chast' 1. Otsenka riska tekhnogennykh avariy i katastrof. Statisticheskaya interpretatsiya ekologicheskogo monitoringa. Modelirovanie i prognozirovanie ekologicheskikh situatsiy. Saint Petersburg: Normed-Izdat, 1998. 208 p.

20. Kim O. Dzh., M'yuller Ch. U., Klekka U. R. Faktornyy, diskriminantnyy i klasternyy analiz. Moscow: Nauka, 1989. 215 p.

21. Trukhacheva N. V. Matematicheskaya statistika v mediko-biologicheskikh issledovaniyakh s primeneniem paketa Statistica. Moscow: GEOTAR-Media, 2012. 384 p.

Kvasnikov Volodymyr, Doctor of Technical Sciences, Honored Metrologist of Ukraine, Head of the Department of Computerized Electrical Systems and Technologies, National Aviation University, Kyiv, Ukraine, e-mail: kvp@nau.edu.ua, ORCID: http://orcid.org/ 0000-0002-7799-0001

Matviyenko Dmitry, Senior Engineer, Testing Laboratory for Food Products and Light Industry Products, State Enterprise «Cherkassy Scientific and Production Center for Standardization, Metrology and Certification»,Ukraine, e-mail: mafik@st.ck.ua, ORCID: http:// orcid.org/0000-0002-7756-5478 